Today 250 million members of the Red Cross and Red Crescent are ready to accomplish such gestures every day, in order to save the lives and relieve the suffering of those who become the victims of natural disasters or man-made catastrophes.

Our Movement continues to base its conviction and determination on the human capacity to be moved by the suffering of others and to refuse to see that suffering as unavoidable.*

\title{
HUMANITARIAN GESTURE
}

\section{Reference paper}

Today is World Red Cross and Red Crescent Day. For the entire Movement. For the millions of members and volunteers-including 90 million young people! —of the 148 National Societies. For the staff and delegates of the ICRC and the League.

This year there are three reasons to celebrate 8 May. Two birthdays and "birthday gifts", in the service of one cause-"protecting human life".

First, today is the anniversary of the birth of our Movement's founder, Henry Dunant. And with him, the birth of a vision, an endeavour and an organization.

Secondly, 1989 World Day is the year of 125 th anniversary of the initial Geneva Convention of 1864 and the 40th anniversary of the 1949 Geneva Conventions.

And finally, the third reason. In response to requests from their National Societies, a number of Governments have today announced a Humanitarian Gesture to mark the 125th anniversary of the Movement and to illustrate-better than any speech - the spirit which guides Red Cross and Red Crescent action.

1. In 1859 , Henry Dunant was horrified to see that thousands of soldiers no longer able to fight were left to die of their wounds, of thirst and hunger, on the battlefield of Solferino.

How can we today not fail to be similarly horrified by the arbitrary, pointless and intolerable acts of violence which are committed throughout the world against so many people? How can we not want these cruel acts-a shame to all humanity-to stop?

How can we remain impassive and not do everything possible to protect the life and ease the suffering of all those who, accidentally or unjustly, are the victims of man-made catastrophes or natural disasters? 
In the past as in the present, the International Red Cross and Red Crescent Movement has based its conviction on this capacity to be moved by the suffering of others and to refuse to accept that suffering as inevitable.

In the words of Henry Dunant, "War, the science of chaos, kills not only the body but all too often the soul as well. It abases, corrupts, tarnishes and degrades. In the face of war and its demands there can be no freedom, no fraternity, no family, no friends, no neighbours, nor even any conscience."

He went on, "The enemy, our true enemy, is not the nation next door, it is hunger, cold, poverty, ignorance, routine, superstition, preconceived ideas." (Both texts taken from L'avenir sanglant, by Henry Dunant).

The Movement founded by Henry Dunant has gone on to become the largest humanitarian institution in the world. All its members share a common goal: to assist those who suffer, no matter what their nationality, race, condition, religion or political opinions.

The National Red Cross and Red Crescent Societies teach first aid in the furthest reaches of the world. Under the Red Cross or Red Crescent banner, the symbol of neutrality, the Movement's members are present in all the "hot spots" in our strife-ridden world. They are always among the first to arrive on the spot, be it after an earthquake or a flood, during a conflict or a famine.

The delegates of the International Committee of the Red Cross will go anywhere in the world to provide protection to prisoners of war and security detainees. They protect and assist the civilian victims of conflict, also giving them medical aid, they work to reunite families separated by events, and they try to spread understanding and encourage acceptance by combatants of the rules of International Humanitarian Law.

When disaster strikes, the delegates of the League of Red Cross and Red Crescent Societies catch the first flight to the place of the disaster, to bring relief to the victims.

Throughout the world, the Movement's volunteers and staff provide assistance-sometimes at the risk of their lives-to those who have lost everything, including their country. They protect children from the effects of desertification, planting trees and digging wells. They also protect the victims of AIDS from the hostility of a society which tends to shut them out.

Henry Dunant's dream was of a universal and neutral Movement, bringing together motivated men and women who "would act whenever and wherever" necessary.

Today, 125 years later, his dream has become reality. But everywhere in the world, the need to protect human life is greater than ever. 
2. Let us now go on to the second reason which, this year, gives special significance to World Red Cross and Red Crescent Day.

Almost 125 years ago to the day, on 22 August 1864, the initial Geneva Convention was signed. By making this decisive commitment for a more humane world, governments for the first time guaranteed protection for the victims on the battlefield.

Then and now, the chain of fellowship, love and understanding represented by the Red Cross and Red Crescent depends on the support and co-operation of the States, which have united for humanity and undertaken to protect human life by becoming party to the most widely-accepted of treaties.

As the 20th century draws to an end, the solution to the major problems of our time cannot be dissociated from respect for the universal values on which humanitarian endeavour is based. Whether protecting human life or alleviating suffering, fighting hunger and disease, promoting understanding and co-operation, no lasting progress can be made unless measures are taken to safeguard the life and dignity of every human being.

We must redouble our efforts to encourage this new awareness and new realism, to persuade people to convert their way of thinking and redirect their energies; to bring out clearly the convergence of interests of all types and the human values common to all civilizations; for a new approach to humanitarian undertakings, for their justification lies not only on moral grounds but also in practical necessity.

The prevailing tendency, it is true, is to give precedence to immediate political imperatives over humanitarian considerations. Man's deeds every day contradict the principles he espouses. However, the cessation of hostilities, the start of negotiations in many conflict areas, the progress made on disarmament and human rights, are all good omens for regaining the humanitarian initiative and taking the offensive on the humanitarian front.

The determination to talk, to act for reconciliation and peace, is therefore not in vain. The endeavours of the United Nations, understanding and co-operation between the big powers, the search for a peaceful solution to conflict, have already given renewed hope and courage to entire peoples, have eased their suffering and saved lives.

None of this has given rise in us, however, to naive optimism or self-defeating pessimism.

In 125 years we have seen ample proof that humanitarian ideals are not pipedreams. With the co-operation and the support of the States party to the Geneva Conventions, the humanitarian action of the Red Cross and Red Crescent has saved milions of victims from death, humiliation and oblivion. 
But how many people are there in the world today-men, women, childrenwho still wait for the protection and assistance to which they are entitled? How many tens and hundreds of thousands have appealed from the depths of their distress and their solitude?

No human being, no government, can and will turn a deaf ear to these appeals and remain indifferent to the suffering of so many victims. To act calls for a humanitarian mobilization of all our energy in order to:

- make the "humanitarian reflex" second nature to those in power,

- encourage trends which advocate respect for humanitarian principles,

- spread knowledge of the effectiveness and impartiality of our activities for all the victims, with a view to increasing the Movement's freedom and means of action.

The Movement's priority for the coming decade, this humanitarian mobilization implies unremitting effort to win over the States and public opinion to the ideals and principles of the Red Cross and Red Crescent.

1989 World Day must further the mobilization and lay the foundations for a renewed commitment, which the States shall be invited to share on the occasion of the ceremonies to commemorate the anniversary of the Geneva Conventions, on 22 August 1989 in Berne, and on 13 October 1989 in New York on the occasion of the United Nations General Assembly.

3. But there is a third dimension, the most immediate and the most tangible, which the Movement wished to give this World Red Cross and Red Crescent Day and which is very much in line with the call for a humanitarian mobilization.

We wanted the States in which there is a National Red Cross or Red Crescent Society to mark the 125th anniversary not only with good wishes but also by a special effort-neither exorbitant nor necessarily spectacular-to encourage the permanent work of the Movement and thereby directly or indirectly ameliorate the plight of the underprivileged, the discouraged, the forgotten.

This was the request made to their respective governements by many National Societies, in the hope of inciting countries on all five continents to make a series of humanitarian gestures in the best tradition of Henry Dunant. Their appeal was heard. According to the information transmitted to us by the National Societies and, in the case of some countries, by the authorities themselves, many Governments have decided on such a humanitarian gesture to commemorate the 125 th anniversary of the Movement.

The gestures are most often very practical: measures for refugees or displaced persons, for separated families or detainees, financial and administrative measures for the benefit of National Societies, educational measures 
for the dissemination of the Red Cross and Red Crescent principles and of International Humanitarian Law, legislative measures such as the ratification of the Additional Protocols or the adoption of a law to protect the emblem. A birthday gift from each State to the National Society, messages of compassion and conciliation, these humanitarian gestures are a very special way of marking 125 years of solidarity with the victims of conflicts and disasters, 125 years during which our fundamental principles have been faithfully upheld and the Movement's unity has overcome borders and differences. This is why these humanitarian gestures have been recorded in a Roll of Honour, opened several days ago for signature by State representatives. Other humanitarian gestures will probably be announced in the coming days. We are confident that many States will take the opportunity to make another entry in the Roll of Honour, which will be open for signature until 22 August 1989.

Every humanitarian gesture helps forge a spirit of mutual aid, understanding and co-operation. To the fist raised in anger it proffers a hand in friendship, and in the midst of violence and disaster, establishes a link of trust and brotherhood.

Every humanitarian gesture helps foster a spirit of peace, because it is not based on domination and fear, but on respect for the human being: it proves that, in the face of suffering, men can cease to be enemies and be shaken out of their indifference to help their fellow man.

The humanitarian gestures announced today will lead to others. They will all encourage a climate of confidence, the mobilization necessary to meet humanitarian emergencies and the building of a more brotherly, just and peaceful world. 